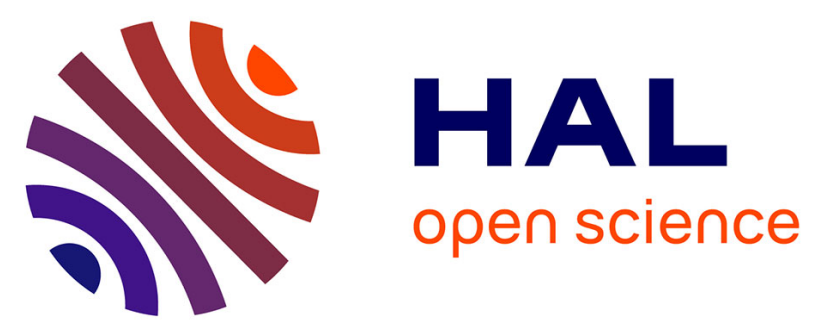

\title{
Profiling metal contamination from ultramafic sediments to biota along the Albanian shoreline of Lake Ohrid (Albania/Macedonia)
}

Laetitia Minguez, Elisabeth M Gross, Davide A.L. Vignati, Ana Romero

Freire, Estelle Camizuli, Frédéric Gimbert, Céline Caillet, Sandrine

Pain-Devin, Simon Devin, François Guérold, et al.

\section{To cite this version:}

Laetitia Minguez, Elisabeth M Gross, Davide A.L. Vignati, Ana Romero Freire, Estelle Camizuli, et al.. Profiling metal contamination from ultramafic sediments to biota along the Albanian shoreline of Lake Ohrid (Albania/Macedonia). Journal of Environmental Management, 2021, 291, pp.112726. 10.1016/j.jenvman.2021.112726 . hal-03325563

\section{HAL Id: hal-03325563 \\ https://hal.univ-lorraine.fr/hal-03325563}

Submitted on 25 Aug 2021

HAL is a multi-disciplinary open access archive for the deposit and dissemination of scientific research documents, whether they are published or not. The documents may come from teaching and research institutions in France or abroad, or from public or private research centers.
L'archive ouverte pluridisciplinaire HAL, est destinée au dépôt et à la diffusion de documents scientifiques de niveau recherche, publiés ou non, émanant des établissements d'enseignement et de recherche français ou étrangers, des laboratoires publics ou privés. 
Profiling metal contamination from ultramafic sediments to biota along the Albanian shoreline of Lake Ohrid (Albania/Macedonia)

Laetitia Minguez $^{\mathrm{a} *}$, Elisabeth M. Gross ${ }^{\mathrm{a}}$, Davide A.L. Vignati ${ }^{\mathrm{a}}$, Ana Romero Freire ${ }^{\mathrm{a}}$, Estelle Camizuli $^{\mathrm{b}}$, Frédéric Gimbert ${ }^{\mathrm{b}}$, Céline Caillet ${ }^{\mathrm{c}}$, Sandrine Pain-Devin ${ }^{\mathrm{a}}$, Simon Devin ${ }^{\mathrm{a}}$, François Guérold $^{\mathrm{a}}$, Laure Giambérini ${ }^{\mathrm{a}}$

${ }^{\text {a }}$ Université de Lorraine, CNRS, LIEC, F-57000 Metz, France

${ }^{\text {b }}$ UMR CNRS 6249 Chrono-Environnement, University of Bourgogne Franche-Comté, 16 route de Gray, 25030, Besançon Cedex, France

${ }^{\mathrm{c}}$ Université de Lorraine, CNRS, LIEC, F-54000 Nancy, France

*Corresponding author: Tel.: +33 (0)372 748927; fax: +33 (0)372 748974

Email address: laetitia.minguez@univ-lorraine.fr (L. Minguez). 


\section{Abstract}

Ultramafic sediments exhibit high levels of geogenically-derived and potentially toxic metals, with $\mathrm{Ni}, \mathrm{Cr}$ and Co often exceeding benchmark values. As yet, a holistic understanding of the bioavailability, mobility, potential ecotoxicity and trophic transfer of trace elements in both benthic and pelagic food chains in aquatic ultramafic environments (UME) is lacking. We investigated potential environmental health issues due to metal contamination by jointly implementing chemical, ecological and toxicological tools, along the Albanian shoreline of Lake Ohrid. It is an aquatic system of worldwide importance, representative of temperate UME with a legacy of $\mathrm{Ni}$ and $\mathrm{Cr}$ contamination from mining activities. Levels of $\mathrm{Ni}, \mathrm{Cr}, \mathrm{Cd}, \mathrm{Cu}, \mathrm{Co}$, $\mathrm{Fe}, \mathrm{Mn}$ and $\mathrm{Zn}$ were determined in waters, sediments and native biota. The potential environmental mobility of sediment-bound elements was further assessed using $\mathrm{CaCl}_{2}$, EDTA and acetic acid extractions. Whole-sediment ecotoxicity tests were also carried out using ostracods and chironomids, according to standardized procedures. Despite $\mathrm{Ni}$ and $\mathrm{Cr}$ concentrations above the sediment quality guidelines for probable effect levels, we did not observe ecotoxic effects in laboratory tests. However, these elements were bioavailable to native organisms under field conditions, especially to benthic primary producers in direct contact with sediments (up to $139 \mathrm{mg} \mathrm{Cr} \mathrm{kg}^{-1}$ and $785 \mathrm{mg} \mathrm{Ni} \mathrm{kg}^{-1}$ ). Although biomagnification was not observed, further investigations of metal translocation, metabolism and elemental trophic transfer along benthic food webs appears to be a general research priority in the management of temperate UME. The present study shows that proper management of temperate UME requires not only the integration of data from different lines of evidence, but also laboratory vs. field approaches to understand the subtler, long-term effects of increased elemental body burdens in native organisms.

Keywords: Heavy metals, trophic transfer, Freshwater organisms, Ancient lake, Serpentine ecotoxicology 


\section{Introduction}

Ultramafic environments (UME) present unique challenges for environmental risk assessors and managers. These ecosystems are naturally characterized by high levels of potentially toxic elements (e.g., $\mathrm{Ni}, \mathrm{Cr}, \mathrm{Co}$ ) and challenging edaphic conditions such as low $\mathrm{Ca}: \mathrm{Mg}$ ratios and low overall concentrations of macronutrients (Bani et al, 2014; Marescotti et al, 2019). UME are found worldwide in ophiolite belts along tectonic plate margins (Circum-Pacific margin and Mediterranean Sea) and are frequent in Europe (Gwenzi, 2020). In particular, ultramafic substrates cover $11-15 \%$ of the total Albanian surface according to different estimates (Lekaj et al, 2019; Nicolas et al, 1999). Due to their natural characteristics, elemental concentrations measured in UME can exceed environmental quality standards or guidelines by orders of magnitude, which may trigger risk assessment and management programs for protecting environmental and human health. Nickel concentrations in ultramafic soils can reach 10,000 $\mathrm{mg} \mathrm{kg}{ }^{-1}$ compared with a global average concentration of only about $16 \mathrm{mg} \mathrm{kg}^{-1}$. Chromium concentrations up to $30,000 \mathrm{mg} \mathrm{kg}^{-1}$ have been found in soil of New Caledonia (Hseu et al, 2018). High levels of the human carcinogenic $\mathrm{Cr}(\mathrm{VI})$, exceeding the WHO drinking water quality guideline of $50 \mu \mathrm{g} \mathrm{L}^{-1}$, have also been reported in UME surface and groundwater as reviewed by Gwenzi (2020). Finally, UME are often mined for $\mathrm{Ni}$ and $\mathrm{Cr}$ ores, which can exacerbate the potential risks linked to the geogenically high elemental levels during extraction and leave a legacy of contaminated waste heaps and sediments in the absence of appropriate decommissioning procedures. When using conceptual approaches such as DPSIR frameworks (Driver, Pressure, State Change, Impact, Response - Gari et al, 2015) in UME management, it is therefore important to gather information to distinguish Pressures, State Changes and Impacts associated with natural Drivers (i.e., basin geology) from those originating from anthropogenic causes (e.g., changes in land use and mining). While the origin of trace elements is immaterial in relation to their ecotoxic potential, management Responses will obviously differ depending 
on their actual Drivers. Proper assessment of environmental and human health risks in UME actually requires combined information on elemental chemistry, ecotoxicity, bioaccumulation and trophic transfer of contaminants to avoid unnecessary interventions or leaving actual environmental risks unmanaged (Burton, 2018).

Most studies in UME have been concerned with geochemistry, terrestrial plant ecology and the ability of terrestrial plants to hyperaccumulate metals for remediation or agromining purposes (Bani et al, 2013; Vithanage et al, 2019, Gwenzi, 2020). However, none of the existing studies seems to have simultaneously examined bioavailability, mobility, potential ecotoxicity and trophic transfer of trace elements in both benthic and pelagic food chains in a given UME; although benthic and pelagic habitats are strictly coupled (Baustian et al, 2014; Vadeboncoeur et al, 2002).

In the present study, we examine the elemental mobility, ecotoxicity and trophic transfer of sediment-bound trace elements at five sites along the Albanian shoreline of Lake Ohrid; a major European diversity hotspot and representative temperate UME with a legacy of sedimentary Ni and Cr contamination (Malaj et al, 2012, Lorenschat et al, 2014). Measured concentrations of $\mathrm{Ni}$ and $\mathrm{Cr}$ in Albanian soils reach around 3,000 mg kg${ }^{-1}$ and 2,400 $\mathrm{mg} \mathrm{kg}^{-1}$, respectively (Bani et al, 2013, 2014) and sedimentary concentrations of up to $1600 \mathrm{mg} \mathrm{kg}^{-1}$ and $700 \mathrm{mg} \mathrm{kg}^{-1}$ have been reported (Malaj et al 2012). Because trace metals from historical mining sites can still be bioavailable to organisms years after decommissioning (Camizuli et al, 2018), metal contamination of Lake Ohrid remains an important local issue and its study can provide a reference point for other UME in Albania or, more in general, in temperate European areas. Besides $\mathrm{Ni}$ and $\mathrm{Cr}$,, we also determined levels of $\mathrm{Cd}, \mathrm{Cu}, \mathrm{Co}, \mathrm{Fe}, \mathrm{Mn}$ and $\mathrm{Zn}$, considering their possible potential to act as additional stressors or to bioaccumulate/biomagnify in local food webs. The potential environmental mobility of sediment-bound elements was assessed using various partial extraction procedures, while two sediment-contact bioassays with the ostracod 
Heterocypris incongruens and the midge larva Chironomus riparius were performed to study the actual ecotoxicological potential of the same sediment. To the best of our knowledge, no data about ultramafic whole-sediment ecotoxicity tests are available in the literature. Native organisms from Lake Ohrid were also sampled to quantify their total element burden as an integrated indicator of metal bioavailability, bioaccumulation and trophic transfer under in situ conditions.

\section{Materials and Methods}

\subsection{Study area}

We selected five sites along the Albanian shoreline of Lake Ohrid based on their expected levels of metal contamination following past mining activities and catchment mineralogy (Malaj et al, 2012). The first site, at the south end of the Lake in an urbanized area, was considered as control site with possibly low metal levels due to the geology of its catchment (fluvial/lacustrine sediment) (Pogradec or "Pog" in the following, N 4054'03.62" E 2042'08.36"). Three sites were located along the ultramafic shoreline of the lake: one in the vicinity of a Fe-Ni dump site at Memëlisht (“Mem”, N 4055'53.53" E 20³8'28.60"), another near a creek mouth at Pojskë ("Poj”, N 4059'59.05" E 20³8'07.61"), and a third close to the mouth of a creek flowing near

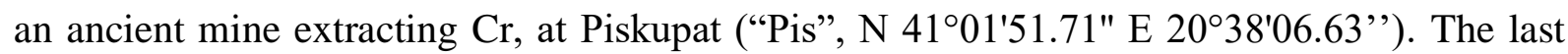
study site, at Lin (“'Lin”, N $41^{\circ} 03^{\prime} 03.55^{\prime}$ E $20^{\circ} 38^{\prime} 45.15^{\prime \prime)}$ was chosen as a slightly contaminated site since its catchment was calcareous and no high metallic concentrations were expected in water and sediment.

\subsection{Sampling and characterization of waters and sediments}

In early September 2016, we collected surface waters and sediments in each sampling site. Surface water samples were collected and preserved in acid-washed polyethylene containers. Samples were either directly acidified by adding $1 \%(\mathrm{v} / \mathrm{v})$ concentrated ultrapure nitric acid for 
later analyses of total metal contents, or first filtered through syringe Millex filters (PVDF; 0.45 $\mu \mathrm{m}$ nominal pore size) and then acidified as above for later measurements of dissolved metal concentrations. A fraction of each water sample was filtered through pre-combusted GF/F filters (Whatman), and was not acidified to quantify dissolved organic carbon. All samples were stored at $4{ }^{\circ} \mathrm{C}$ pending analysis. Water temperature, dissolved oxygen, conductivity and $\mathrm{pH}$ were measured in situ with WTW probes.

At each site, the upper $10 \mathrm{~cm}$ of sediment were collected at three points about a meter apart, using a stainless-steel shovel and well mixed to obtain one composite sample, representative of each site. Samples were placed in polyethylene containers and stored at $4^{\circ} \mathrm{C}$ until further processing. Representative subsamples of each sediment were dried at $65^{\circ} \mathrm{C}$ for $72 \mathrm{~h}$ and sieved to $<2 \mathrm{~mm}$ fraction. Pseudo-total metal concentrations were determined by digesting sediments in aqua regia. The potential availability of sediment-bound metals was further evaluated using four widely applied procedures: (1) the mobile amounts of metals through $0.01 \mathrm{M} \mathrm{CaCl}_{2}$ extraction (Houba et al, 1990); (2) the potentially phytoavailable fraction through $0.05 \mathrm{M}$ EDTA extraction (Ure et al, 1993); (3) the mobilizable pool by treating subsamples with 0.11 M acetic acid (Quevauviller et al, 1997); and (4) the amorphous Fe, Mn and Al oxides through the $0.2 \mathrm{M}$ acid ammonium oxalate extraction in the dark (Schwertmann, 1964). The above chemical procedures have been validated by a certified reference material BCR ${ }^{\circ} 701$ (European Commission) helping to monitor potential pitfalls that may occur during extractions. Particle size distribution was determined by laser diffraction granulometry (SympaTEC Helos $\mathrm{BF}$ granulometer) on a smaller fraction further sieved to $<1 \mathrm{~mm}$ and expressed as dry-weight (DW) percentage. Sediment total organic carbon (TOC) was determined by loss on ignition at $550^{\circ} \mathrm{C}$ (APHA, 2005). Details on the different analytical procedures are given in Supporting Information (SI Methods).

\subsection{Chronic Bioassays}


We performed two chronic bioassays to assess the potential toxicity of sampled sediments, using two sediment-dwelling species. First, the ostracodTox test, using neonates $(<52 \mathrm{~h}$ old $)$ of the benthic crustacean Heterocypris incongruens (Ramdohr, 1808), consists in putting the ostracods in contact with a sediment for 6 days (MicroBioTest, 2001) and in measuring their survival and length at the end of the exposure period, as a proxy of growth. The second bioassay was the 28-day Chironomus riparius test following the OECD guideline 218 (2004). Survival and growth (mass and length) of larvae after 10 days and the emergence of adults after 28 days were measured (for more details, see SI Methods). As the amount of sediment from Lin was limited, only sediments from Pog, Mem, Poj and Pis (i.e. the control sediment and the three sediments under ultramafic influence) were tested for their ecotoxicity to chironomids.

\subsection{Aquatic biota sampling}

Biota samples $(\mathrm{n}=257)$ were collected at the same time as waters and sediments to quantify in situ bioaccumulation by organisms from different taxa and feeding guilds and define their trophic level (Table S1): (i) Benthic and pelagic primary producers: The periphytic biofilm was collected by brushing rock surfaces with a medium bristled toothbrush. Large organisms were removed by filtration through an $80-\mu \mathrm{m}$ mesh nylon filter. Specimens of the submerged aquatic plant Myriophyllum spicatum L. (Haloragaceae) were collected at two-meter depth by snorkeling. In the lab, plants were separated into leaves, stems and belowground parts (roots and rhizomes). The latter were not analyzed in this study since they are not accessible for grazers. Phytoplankton was sampled offshore during daylight by two vertical tows, from $15 \mathrm{~m}$ depth to the surface using a net of 34- $\mu \mathrm{m}$ mesh size, then filtered through an $80-\mu \mathrm{m}$ mesh nylon filter to remove larger organisms. (ii) Benthic and pelagic consumers: Benthic invertebrates were hand-collected in the littoral zone and included amphipods (gammarids), bivalves (Unio tumidus and Dreissena carinata, synonym of D. stankovici and D. presbensis) and gastropods (Radix relicta). After collection, organisms were rinsed with ultrapure water. A batch of 
individuals of each taxon was depurated for $48 \mathrm{~h}$ to verify the possible contribution of gut content to metal accumulation in the sampled organisms. Another batch was not depurated since predators are exposed to both digestive lumen contents and prey tissues. A third batch of gutpurged invertebrates was taken for stable isotope analyses (see section 2.6). All organisms were finally frozen in liquid nitrogen. Bivalves and gastropods were removed from their shells before snap-freezing in liquid nitrogen. Zooplankton was sampled offshore during daylight by two vertical tows, from $15 \mathrm{~m}$ depth to the surface using a net of $83-\mu \mathrm{m}$ mesh size. (iii) Fish species: At least three individuals of five fish species were obtained from fishermen: Alburnus albidus (size range: 10.9-11.6 cm), Barbus meridionalis petenyi $(9.2-9.9 \mathrm{~cm})$, Leuciscus cephalus albus $(10.2-13.3 \mathrm{~cm})$, Rutilus ohridanus $(7.7-9.3 \mathrm{~cm})$ and Salmo letnica $(20-25 \mathrm{~cm})$, the last two species being endemic of this lake. Muscles were dissected, snap frozen in liquid nitrogen and stored at $-80^{\circ} \mathrm{C}$ until further processing. All biological samples were freeze-dried before metal analyses. Not every organism was found at each site (Table S1).

\subsection{Metal analysis}

Aqueous concentrations of $\mathrm{Cd}, \mathrm{Cr}, \mathrm{Cu}, \mathrm{Mn}, \mathrm{Ni}$ were determined by graphite furnace atomic absorption spectrophotometry (VARIAN Spectraa 800 with ZEEMAN correction), while Fe and $\mathrm{Zn}$ were determined by flame atomic absorption spectrophotometry (FAAS) (Perkin-Elmer Aanalyst 100). Surface water SPS-SW1 (Batch 120) was used as quality control material. In sediments and biota, $\mathrm{Cd}, \mathrm{Co}, \mathrm{Cr}, \mathrm{Cu}, \mathrm{Fe}, \mathrm{Mn}, \mathrm{Ni}$, and $\mathrm{Zn}$ were quantified by FAAS after mineralization. Sediments $(500 \mathrm{mg})$ were digested in $19 \mathrm{~mL}$ aqua regia $\left(\mathrm{HNO}_{3} / \mathrm{HCl}\right.$ ratio $\left.1: 3\right)$ and biota samples in 10 or $19 \mathrm{~mL} 69 \% \mathrm{HNO}_{3}$ (according to the available sample mass: $<100$ $\mathrm{mg}$ or $>100 \mathrm{mg}$, respectively) for $48 \mathrm{~h}$ at $60^{\circ} \mathrm{C}$. All reagents and solvents used for metal analysis were analytical grade. Certified reference material TORT-2 (National Research Council of Canada) was submitted to the same digestion procedure during each analytical run. Percent recovery for elements in certified reference material were as follows: $\mathrm{Cd}(103 \%), \mathrm{Cu}(100 \%)$, 
Co (86\%), Cr (102\%), Fe (98\%), Mn (97\%), Ni (61\%), and Zn (100\%). Data were not corrected for percent recovery.

\subsection{Stable isotopes and trophic level calculations}

Nitrogen isotopes were used to estimate the trophic positions of consumers and carbon isotopes to estimate the carbon flow to consumers in food webs. Carbon $\left(\delta^{13} \mathrm{C}\right)$ and nitrogen $\left(\delta^{15} \mathrm{~N}\right)$ stable isotopes were analyzed on all sampled species at the Service d'Analyse des Roches et des Minéraux (SARM), CRPG (Nancy, France) using a GasBench/isotope ratio mass spectrometer (Thermo Mat 253). Plankton and periphyton were filtered on site using pre-combusted GF/F filters (Whatman) to provide at least $1 \mathrm{mg}$ dry weight of sample on each filter. Filters were treated with $1 \mathrm{M} \mathrm{HCl}$ and dried overnight at $50^{\circ} \mathrm{C}$ to remove inorganic carbon. Dried leaves of aquatic plants, whole tissues of depurated invertebrates, and muscles of fishes were ground to a fine powder using a ball mill (Retsch MM400). Approximately $2 \mathrm{mg}$ of each biological sample were weighed into tin capsules and analyzed. Isotopic ratios were calculated using the following equation:

$\delta \mathrm{X}(\% 0)=\left[\left(R_{\text {sample }} / R_{\text {standard }}\right)-1\right] \times 1000$, where $\mathrm{X}={ }^{13} \mathrm{C}$ or ${ }^{15} \mathrm{~N}$, and $\mathrm{R}=$ corresponding ratio of ${ }^{13} \mathrm{C} /{ }^{12} \mathrm{C}$ or ${ }^{15} \mathrm{~N} /{ }^{14} \mathrm{~N}$. Samples were not delipidated, but since lipid content can impact $\delta^{13} \mathrm{C}, \mathrm{C} / \mathrm{N}$ ratios were measured. Eight international standards of known $\delta^{15} \mathrm{~N}$ and $\delta^{13} \mathrm{C}$ were used (NBS 22, IAEA CH3, IAEA CH6, IAEA CH7, USGS 24, IAEA N1, USGS 25 and Urea IVA). Analytical precision was $\pm 0.1 \%$.

\subsection{Data handling and statistics}

All statistical analyses were performed with $\mathrm{R}$ version 3.6.1 (R Core Team 2019), using the RStudio interface (version 1.0.153).

\subsubsection{Sediment quality and toxic effects}

The Sediment Quality Index (SQI) developed by the Canadian Council of Ministers of the Environment (CCME, 2002) and modified later by Marvin et al (2004), was chosen to describe 
the overall quality of the sediments. The index score was computed for each sample using the probable effect concentrations (PEC) guideline values (Table 1), developed by MacDonald et al (2000). Sediments were classified in five categories according to their SQIs: poor when $0 \leq \mathrm{SQI}<45$, marginal when $45 \leq \mathrm{SQI}<60$, fair when $60 \leq \mathrm{SQI}<80$, good when $80 \leq \mathrm{SQI}<95$, excellent when $95 \leq \mathrm{SQI} \leq 100$ (Marvin et al, 2004). Correlation coefficients between sediment parameters were determined using the Spearman's rank correlation test. Linear regressions between selected variables (see section 3.2 for details) were derived using the least square method.

Differences in survival of $C$. riparius larvae after 10 days of exposure were tested using a generalized linear mixed-effects model (glmer $\mathrm{R}$ package). The relationship between emergence rates and sediments was assessed using a non-linear mixed effect regression model (nlme R package). For both models, the sediment was integrated as fixed effect and the beaker as random effect. Pairwise comparisons were done using a likelihood-ratio test. When a significant relationship was found between emergence rate and sediment, pairwise Wald t-test of the estimated coefficients were carried out between treatments by re-ordering them in nlme models using the relevel $\mathrm{R}$ function (stats $\mathrm{R}$ package). The effect of sediment on the growth of ostracods and chironomids was tested using ANOVA, followed by post-hoc pairwise comparisons using Tukey's HSD test.

\subsubsection{Metal profile of native biota}

Principal component analysis (PCA) was used to summarize the variations in the bioaccumulated concentrations of metals, and to facilitate the comparison between sites and organisms. PCA analysis was performed with the FactoMineR package (Lê et al, 2008) and data were visualized using the factoextra package (Factoextra, 2018). Data did not satisfy the assumptions of normality and variance homogeneity, thus significant differences between metal contents in biota were tested using the Kruskal-Wallis ANOVA and the non-parametric Mann- 
Whitney test for paired comparisons corrected for multiple comparisons using the BenjaminiHochberg procedure. For primary producer and fish data with low sample sizes, we calculated bootstrapped $95 \%$ confident intervals (CIs) of the difference between group medians (BCa method, $\mathrm{R}=1000$ ). When the $95 \%$ CIs of the difference in medians excluded zero, we concluded there was a statistically significant difference in median values between groups.

\subsubsection{Trophic transfer}

Corrections of $\delta^{13} \mathrm{C}$ values were performed when the $\mathrm{C} / \mathrm{N}$ ratio exceeded 3.5. A normalization was applied following the equation of Post et al (2007): $\delta^{13} C_{\text {lipid corrected }}(\% 0)=$ $\delta^{13} \mathrm{C}-3.32+0.99 \times C / N$. Since the $\mathrm{C} / \mathrm{N}$ ratio is not a good predictor of lipid content in aquatic macrophytes, normalization was performed based on the carbon content (Post et al, 2007), following the equation: $\delta^{13} \mathrm{C}_{\text {lipid corrected }}(\% 0)=\delta^{13} \mathrm{C}-3.09+0.09 \times \% \mathrm{C}$. The bivalves Dreissena carinata (Dc) were assumed to occupy a second trophic level $(\mathrm{TL}=2.0)$ as primary herbivores. Trophic levels of other organisms were determined using the following equation: $T L=\left[\left(\delta^{15} N_{\text {org }}-\delta^{15} N_{D c}\right) / 3.4\right]+2$, where $\delta^{15} \mathrm{~N}_{\text {org }}$ is the $\delta^{15} \mathrm{~N}$ signature in a given organism, $\delta^{15} \mathrm{~N}_{\mathrm{Dc}}$ is the mean $\delta^{15} \mathrm{~N}$ value ( $\pm \mathrm{sd}$ ) for $D$. carinata $(3.60 \pm 0.16 \%$ ), and 3.4 is the trophic enrichment factor for $\delta^{15} \mathrm{~N}$ (Post, 2002). The quality of linear regressions between $\log \left[\right.$ metals] and TL was assessed by the squared coefficient of correlation $\left(\mathrm{R}^{2}\right)$, Fisher's criterion $(\mathrm{F})$ and the p-value. The slopes were used to calculate trophic magnification factors $(\mathrm{TMF})$, as TMF $=10^{\text {slope }}$. Trophic magnification and dilution are defined, respectively, by TMF above and below 1 .

\section{Results and Discussion}

\subsection{Metal profile of waters}

The oligohumic (DOC $<4 \mathrm{mg} \mathrm{L}^{-1}$ ) and soft waters (conductivity $<300 \mu \mathrm{S} \mathrm{cm}^{-1}, \mathrm{Ca}<30 \mathrm{mg} \mathrm{L}^{-1}$ ) of Lake Ohrid displayed metal contamination below or in the same range as those found in other 
lakes worldwide (for reviews Chen et al, 2018; Sibal and Espino, 2018). All studied metals were also below threshold concentrations defining a potential environmental hazard condition (EQS) ([dataset] Minguez et al, 2021). Even for the three metals $(\mathrm{Cu}, \mathrm{Ni}$ and $\mathrm{Zn})$ for which bioavailable concentrations can be estimated using "user-friendly" biotic ligand models (www.bio-met.net), no environmental risk is predicted. One should note that all the "userfriendly" biotic ligand models free-available to estimate bioavailable concentrations of $\mathrm{Cu}, \mathrm{Ni}$ and $\mathrm{Zn}$ and the associated environmental risk at a specific site, reach their limit for those ultramafic aquatic ecosystems characterized by high $\mathrm{pH}$ (above $8.5-8.7$ ), rather low hardness and low DOC. All these models have been validated for certain $\mathrm{pH}, \mathrm{Ca}$ and DOC ranges, and the $\mathrm{pH}$ measured in all study sites are equal to or above the upper limits of the validated $\mathrm{pH}$ ranges in the models ( $\mathrm{pH}$ ranges: $6-8.5$ for $\mathrm{Cu}, 6.5-8.7$ for $\mathrm{Ni}$ and 6-8 for $\mathrm{Zn}$ ), meaning that results should be interpreted with caution.

It is essential to confirm this non-exceeding of the EQS by a monitoring at different seasons, thus integrating episodes of precipitation. Lake Ohrid, has a prevailing Mediterranean climate with enhanced precipitation relative to the rest of southern Europe. It is especially supplied with water from surface run-off via creeks and rivers flowing through ultramafic soils (Sinopoli et al, 2019). Rain events could largely determine metal loadings into the lake.

\subsection{Metal profile of sediments}

Sediments were sandy and contained low amounts of organic matter and low (Pog and Mem) to intermediate (Poj and Pis) calcium carbonate. Only sediment from Lin was rich in $\mathrm{CaCO}_{3}$ due to the limestone geology of its shoreline ([dataset] Minguez et al, 2021). High concentrations of $\mathrm{Cr}, \mathrm{Ni}, \mathrm{Fe}$ and $\mathrm{Mn}$ were found at Mem, Poj and Pis, (Table 1). The maximum concentrations of $\mathrm{Cr}\left(345 \mathrm{mg} \mathrm{kg}^{-1}\right)$ and $\mathrm{Ni}\left(554 \mathrm{mg} \mathrm{kg}^{-1}\right)$ were found at Pis and Mem, respectively; i.e. the closest sites to former $\mathrm{Cr}$ or $\mathrm{Ni}$ mines. Mining of $\mathrm{Ni}$ and $\mathrm{Cr}$ was in the form 
of Fe alloys (Malaj et al, 2012), which accounts for the presence of high Fe concentrations, up to $50 \mathrm{~g} \mathrm{~kg}^{-1}$ at Pis, in these sediments. Significant positive correlations ( $r_{S}$ between 0.88 and 1) between the concentrations of $\mathrm{Co}, \mathrm{Cr}, \mathrm{Fe}$ and $\mathrm{Mn}$ (Figure 1) confirmed the co-occurrence of these metals, as already observed by Malaj et al (2012). Metal concentrations in sediments were generally lower than those reported by Malaj et al (2012), especially for $\mathrm{Ni}$ (10-fold) and $\mathrm{Cr}$ (1.5-fold) at Pis and Poj. Further studies are required to determine if such differences simply reflect a patchy distribution of contaminated sediments or decreasing trends in $\mathrm{Cr}$ and $\mathrm{Ni}$ levels. The sediment quality index (SQI) classified sediments from Mem, Poj and Pis as of poor and marginal qualities $\left(\mathrm{SQI}_{\mathrm{Mem}}=37.64, \mathrm{SQI}_{\mathrm{Poj}}=56.34, \mathrm{SQI}_{\mathrm{Pis}}=51.96\right)$. The concentrations quantified in those sites were also higher than or in the same range as those reported in the literature for freshwater sediments considered as severely polluted (e.g. in Tigris River, Varol, 2011; in several Chinese lakes, Xu et al, 2017). Site Lin, not directly linked with any source of pollution (creeks or ore dump sites), displayed an enrichment in $\mathrm{Cr}$ and $\mathrm{Ni}$ concentrations (43 and $75 \mathrm{mg} \mathrm{kg}^{-1}$ ) compared to Pog. In this area, Vogel et al (2010) have reported the occurrence of strong wind-driven surface currents, which redistribute total suspended solids and thus metals in the lake. These currents may explain this enrichment at Lin, lowering sediment status from excellent to good quality ( $\left.\mathrm{SQI}_{\mathrm{Pog}}=100, \mathrm{SQI}_{\mathrm{Lin}}=80.42\right)$.

Correlations with Fe would indicate that the high concentrations of $\mathrm{Cr}$ and $\mathrm{Ni}$ likely originate from natural weathering of ferronickel and chromite minerals found in ultramafic soils (Malaj et al, 2012). For our data, such a correlation exists for Cr, but not for Ni (Figure 1). Single extraction procedures showed that $\mathrm{Ni}$ was generally more mobile than $\mathrm{Cr}$, although the exchangeable fraction was $\leq 0.12 \%$ of the total for both elements (Table 1 ). Sediment extraction with acetic acid (AA) suggested that 3 to $25 \%$ of Ni could be associated with carbonates; while the corresponding figures for $\mathrm{Cr}$ did not exceed $1.6 \%$. In the case of $\mathrm{Ni}$, acetic acid extractable concentrations and EDTA extractable levels (1-16\% of the total) showed similar patterns 
among sampling sites, but the correlation between the two variables was not significant $\left(r_{S}=\right.$ $0.898 ; \mathrm{p}=0.102)$. On the other hand, EDTA extractable $\mathrm{Cr}(0.15-1 \%$ of the total $)$ correlated well with amorphous Mn oxides as estimated by ammonium oxalate extraction $\left(r_{S}=0.982, \mathrm{p}=\right.$ 0.018). In both cases, no correlations were observed between partial and pseudo-total metal concentrations. These results are in agreement with those of Malaj et al (2012) although the comparison must take into account methodological differences in the extraction procedures. Overall, $\mathrm{Ni}$ and $\mathrm{Cr}$ appeared strongly associated with different mineral phases that remain to be better identified. However, partial extraction procedures poorly mimic the actual processes occurring in the digestive apparatuses of particle-ingesting organisms. Thus, additional information on the actual ecotoxicological and bioaccumulation potential of these elements must be directly obtained from other lines of evidence (e.g. assessment of ecotoxicological risk and bioaccumulation).

\subsection{Ecotoxicity screening of sediments}

Ostracods exposed to lake sediments did not show any mortality or growth reduction compared to the non-toxic reference sediment (Figure S1A). The 10-d survival of $C$. riparius ranged from $93 \pm 8 \%$ to $98 \pm 3 \%$, with no significant differences among samples (Figure S1B). Concerning the growth (in mass and length) of midge larvae (Figure 2A) and their emergence (Figure 2B, Table S2), only the sediment from Pog displayed a pattern significantly different from the reference sediment (sand), with the highest growth after 10 days. The sex ratio of adults was on average 0.52 at the end of experiment. Although 3 out of the 5 studied lake sediments displayed metal concentrations exceeding quality guidelines (de Deckere et al., 2011; MacDonald et al., 2000; Vangheluwe et al, 2013), the low amounts of organic matter, the high concentrations of Fe- and Mn-oxides and the low concentrations of metals in the water-soluble fraction imply that $\mathrm{Ni}$ and associated metals were not available and toxic for ostracods and chironomids. 
As metals in lake sediments were not readily available, it is therefore unlikely that the sediment contamination by metals led to the observed variations in the growth and emergence of $C$. riparius larvae. The sandy matrix (reference) leading to similar results as field contaminated sediments also supports this assertion. The low (but significant) delay in growth (Fig. 2A) and emergence (Fig. 2B) may be explained by the absence of organic matter (as a source of food and energy for larvae) in the reference sand sediment. The quantity and/or quality of organic matter in the sediment is probably a key variable explaining the results. Further data analyses or experiments to measure bioaccumulation and the subcellular fate of metals in chironomid tissues would also provide information to better understand these differences (Gimbert et al., 2016). Two final caveats conclude this critical evaluation of these ecotoxicological results. Laboratory experiments with whole sediment cannot account for metal body-burdens originating from (freshly deposited) suspended particulate matter; an exposure route that can strongly contribute to elemental accumulation in chironomids and other organisms (Ferrari et al, 2019). Finally, chironomids may be rather insensitive to elemental contamination and can tolerate metal burdens high enough to eliminate more sensitive taxa from the benthic community occurring at a given site (Bervoets et al, 2016).

\subsection{Metal profile of in situ biota}

Metal concentrations in organisms result from prolonged exposure, making it difficult to link them with ambient aqueous concentrations at the time of sampling (Ravera et al 2003). Thus, we focused on comparing concentrations measured in benthic organisms sampled in at least 3 sites to those in sediments that are more representative of exposure levels over time. Cadmium was not detected in biota and will not be discussed in this section. Concentrations in organisms were better correlated to pseudo-total concentrations in sediments (i.e. aqua regia extraction) than to concentrations found in the different sediment fractions (Figure 3). While EDTA is often considered as the best extractant for phytoavailable metals, $\mathrm{Co}, \mathrm{Cr}$ and $\mathrm{Ni}$ concentrations 
accumulated by the macrophyte $M$. spicatum were better correlated to concentrations in the acetic acid fraction. Under nutrient-limited conditions, such as those encountered in ultramafic environments (Bani et al, 2014; Marescotti et al, 2019), aquatic macrophytes are known to release organic acids from their roots to increase nutrient availabilities, especially by dissolving carbonate complexes (Gunnison and Barko, 1988; Xing et al, 2018). Experimental studies following macronutrient nutrition of macrophytes demonstrated that the uptake pattern of both essential and non-essential elements was similar, from the sediment by the roots followed by a translocation to above-ground tissues (Barko and Smart, 1986; Jackson et al, 1994).

The PCA synthesizes results of the metal contents accumulated by primary producers (phytoplankton, Myriophyllum spicatum and periphytic biofilm) and consumers (zooplankton, Dreissena carinata, Unio tumidus, Radix relicta and Gammarus sp.) from benthic-pelagic food webs (Figure 4). The first two axes explain $80.2 \%$ of the total variance in the data matrix. Factor 1 explains $53.2 \%$ of the total variance and is characterized by measured concentrations of $\mathrm{Cr}$, $\mathrm{Ni}, \mathrm{Fe}$ and $\mathrm{Co}$ in organisms (positive loads: higher concentrations bioaccumulated). This axis discriminates benthic primary producers (Biofilm and $M$. spicatum) from the other organisms. Factor 2 explains $27.0 \%$ of the total variance and is defined by concentrations of $\mathrm{Zn}$ and $\mathrm{Cu}$ in consumers. This axis distinguishes zooplankton and $U$. tumidus from the other organisms. The highest concentrations of $\mathrm{Cr}$ and $\mathrm{Ni}$ were found in benthic primary producers from the three most polluted sites (Mem, Poj and Pis) (Figure 4, Figure S2). Maximum levels of $\mathrm{Cr}$ and Ni in biofilms were $95 \mathrm{mg} \mathrm{kg}^{-1}$ and $785 \mathrm{mg} \mathrm{kg}^{-1}$, respectively; while the corresponding concentrations for M. spicatum reached $115 \mathrm{mg} \mathrm{kg}^{-1}$ and $461 \mathrm{mg} \mathrm{kg}^{-1}$. Several submerged macrophyte species, such as Myriophyllum spp., and biofilms are known to exhibit high accumulation capability for metals (Cardwell et al, 2002; Geng et al, 2019; Harguinteguy et al, 2015; Xing et al, 2013). Rooted species can extract metals either from the sediment via their roots or from the surrounding water via their shoots. Others (e.g. Ceratophyllum demersum and Vallisneria 
natans) can even hyperaccumulate metals such as Cr (Xing et al, 2013). In Lake Ohrid, the threshold for hyperaccumulation of $\mathrm{Cr}$ and $\mathrm{Ni}$ was not reached (i.e. 1,000 $\mathrm{mg} \mathrm{kg}^{-1}$ ) (Reeves and Baker, 2000). Metals accumulated in stems and leaves might ultimately be transferred to herbivores when plant tissues are consumed. Similarly, metals could be released during macrophyte senescence through leaching, mineralization and microbial degradation, and thus become available to detritus feeders (Weis and Weis 2004). The different patterns of metal concentrations between macrophytes and biofilm suggest that the latter have a higher ability to accumulate metals compared to $M$. spicatum. However, we cannot exclude the fact that biofilms also contained some resuspended particles from sediments or trapped sinking suspended particles. A separation of the living (algae, bacteria, meiofauna) and dead fractions (suspended particles) of a biofilm is not possible without loss of biotic material, and is also unlikely to happen during consumption of biofilm by most grazers, such as snails.

Composite samples of phytoplankton showed lower metal contents (e.g. ranges for Cr: 5-38 mg $\mathrm{kg}^{-1}$ and Ni: $10-116 \mathrm{mg} \mathrm{kg}^{-1}$ ) compared to benthic primary producers. Several factors influence the accumulation of metals in phytoplankton such as the productivity of the water body, the physicochemical properties of the water, the composition of phytoplankton and the season (Mazej et al, 2010). In oligotrophic lakes, benthic primary production dominates, and since benthic primary producers are more effective at sequestrating nutrients, they regulate the availability of sediment nutrients to phytoplankton (Vadeboncoeur et al, 2002). Metals, some of which are essential for plants, may follow the same process, resulting in higher metal concentrations in benthic primary producers than in pelagic ones.

Consumers accumulated less metals than primary producers (negative coordinates in the first PCA-axis, Figure 4). The 48h-depuration period did not significantly affect measured metal concentrations, except for non-depurated gammarids from Mem that showed 32 and 50\% higher values for $\mathrm{Fe}$ and $\mathrm{Ni}$ compared to the corresponding depurated specimen (Figure S3). This 
suggests that in general the gut contents did not significantly contribute to the concentrations measured in consumers. Significant interspecific differences were found, even between taxonomically similar species (Figure 4, Figure S4). The highest concentrations of $\mathrm{Ni}$ and $\mathrm{Cr}$ in invertebrates were found at Mem, Poj and Pis, similar to the pattern found for primary producers. Bivalve mollusks have been commonly used to assess the levels of contamination, since these organisms provide a time-integrated measure of metal bioavailability (Rzymski et al, 2014). In the present study, metal concentrations differed between the two studied bivalve species. $\mathrm{Cr}$ and $\mathrm{Zn}$ concentrations in $U$. tumidus were 4-6 times higher than those found in $D$. carinata, whereas $\mathrm{Ni}, \mathrm{Co}$ and $\mathrm{Cu}$ concentrations were almost 2 times lower in U. tumidus than in D. carinata. These findings are in agreement with those of Rzymski et al (2014), who observed that $U$. tumidus was able to accumulate high $\mathrm{Cr}$ contents and, suggested using this species as a bioindicator of $\mathrm{Cr}$ contamination. However, metal accumulation in bivalves strongly depends on biotic and abiotic parameters, making interspecific comparison between species difficult. Accumulation can be a function of age, size, feeding activity, physiology of organisms and the physicochemistry of the surrounding environment (Boening, 1999). Dreissena carinata were smaller than $U$. tumidus and the habitat of $D$. carinata is related to the water-column whereas sediments define the habitat of $U$. tumidus.

Gastropods, $R$. relicta, were the highest accumulators of metals $\left(17 \mathrm{mg} \mathrm{Cr} \mathrm{kg}^{-1}\right.$ at Poj and 252 mg Ni kg-1 dry weight at Mem, respectively). Unlike bivalves, which are filter-feeders of phytoplankton displaying low metal concentrations, the feeding habit of gastropods involves grazing of epiphytes, periphyton and aquatic macrophytes, which accumulated the highest concentrations of metals among all studied organisms (Figure S2, S4). On the other hand, gammarids were characterized by higher $\mathrm{Cu}$ concentrations and zooplankton by higher contents of $\mathrm{Cu}$ and $\mathrm{Zn}$ compared with other studied organisms. $\mathrm{Cu}$ and $\mathrm{Zn}$ are essential elements and are regulated by physiological mechanisms in most organisms. In crustaceans, these two metals are 
required for the functioning of both enzymatic (e.g. carbonic anhydrase a $\mathrm{Zn}$-containing protein) and non-enzymatic proteins (e.g. proteins $\mathrm{Cu}$-associated with respiratory processes such as the respiratory pigment hemocyanin) (White and Rainbow, 1985). Estimations of the amount of $\mathrm{Cu}$ and $\mathrm{Zn}$ needed for these protein activities yield values of $83 \mathrm{mg} \mathrm{Cu} \mathrm{kg}^{-1}$ and 68 mg Zn kg ${ }^{-1}$ dry weight (Depledge, 1989). Observed concentrations in Gammarus spp. were close to the metabolic requirements for both metals, thus they did not show abnormal metal contents. However, measured contents for zooplankton are greater than the estimated metabolic requirements. Possible explanations include the fact that they feed on phytoplankton, which was also rich in $\mathrm{Zn}$ and $\mathrm{Cu}$, and zooplankton may be slow to metabolize or excrete these metals. Knowledge of metal concentrations in fish is important for both conservation purposes and management of the human consumption of fish (Papagiannis et al, 2004). In Lake Ohrid, fishes displayed even lower concentrations in their muscles than primary consumers, with no strong differences between species in non-essential element concentrations (Figure 5). These results are in agreement with the concentrations below detection limits observed by Malaj et al (2012) on S. letnica and Salmo ohridanus in Lake Ohrid. One reason for this low accumulation in fishes could be their continuous migration to uncontaminated parts of the Lake (Malaj et al, 2012), such as the pelagic zone where organisms (phytoplankton and zooplankton) showed low concentrations. It should also be noted that these concentrations were measured in muscles and not on the whole organism as for the invertebrates. Muscles are known to display lower capacity of contaminant accumulation compared to other tissues such as the liver and intestine. Knowledge of fish behaviors in this area and a better understanding of their detoxifying metabolism integrating other tissues are necessary to draw conclusions about this biotic compartment. The consumption of these edible parts would not present a health risk. Estimated daily intake of metals considering an adult of $70 \mathrm{~kg}$ with a mean consumption of $8 \mathrm{~g}$ per day 
(FAO, 2015) would be exposed to concentrations much lower than tolerable daily intake defined by the World Health Organization.

\subsection{Transfer of metals along food webs}

Mean values of stable $\delta^{15} \mathrm{~N}$ isotope signatures ranged from 2.6 to $11.8 \%$ (without considering the enrichment factor) (Figure S5). Four trophic levels were identified, with primary producers representing the bottom trophic level in studied food webs (lowest values of $\delta^{15} \mathrm{~N}$ ). All metals analyzed in this study showed a decrease of concentrations with increasing trophic level, except Zn which showed no variations in concentrations between trophic levels (Figure 6, Figure S6). These regressions resulted in a trophic magnification factor (TMF) of 0.16 for $\mathrm{Cr}$ ( slope $=-0.79$ $\left.\pm 0.09, \mathrm{R}^{2}=0.52, \mathrm{~F}=68.41, \mathrm{p}<0.001\right), 0.07$ for $\mathrm{Ni}\left(\right.$ slope $=-1.15 \pm 0.09, \mathrm{R}^{2}=0.69, \mathrm{~F}=138.2$ $\mathrm{p}<0.001$ ), and 0.37 for $\mathrm{Cu}$ (slope $=-0.43 \pm 0.08, \mathrm{R}^{2}=0.29, \mathrm{~F}=26.67, \mathrm{p}<0.001$ ). The TMF for the other metals (Co, Fe and $\mathrm{Mn}$ ) were around 0.2. Our results are consistent with the concept of trophic dilution, defined by a decrease in contaminant concentration as trophic level increases (Nordberg et al, 2009), and agree with previous studies reporting that these metals generally do not biomagnify in food chains (Cardwell et al, 2013; Cui et al, 2011; Ward et al, 2012). However, $\mathrm{Zn}$ biomagnification may occur where ambient $\mathrm{Zn}$ concentrations are deficient or less than optimal (Cardwell et al, 2013; Ward et al, 2012). For Zn, which showed different patterns of trophic transfer, the assessment of subcellular bioaccumulation could provide insight into $\mathrm{Zn}$ handling strategies by organisms from Lake Ohrid (Rosabal et al, 2014). It is noteworthy that even if biomagnification is unlikely when food chains are studied as a whole, the transfer of metals from a food source to its consumer (i.e. trophic transfer or "biotransference" as used by the following authors) can occur (Barwick and Maher, 2003), as observed here between phytoplankton and zooplankton (for $\mathrm{Cu}, \mathrm{Cr}, \mathrm{Ni}$ and $\mathrm{Zn}$ ) or D. carinata (for Ni). Several cases of trophic transfer were reported in aquatic ecosystems between primary 
producer species and their invertebrate consumers, especially for $\mathrm{Cu}$ and $\mathrm{Zn}$ (Barwick and Maher, 2003; Jara-Marini et al, 2009; Wang, 2002).

\section{Conclusion}

Sediments from the Albanian shoreline of Lake Ohrid can still exhibit Ni and Cr concentrations above quality guidelines for probable effect levels. However, the present study provides first time evidence that such concentrations do not elicit direct ecotoxic effects on model ostracods and chironomids in standardized laboratory tests. On the other hand, both elements appear to be bioavailable to indigenous organisms under field conditions, especially to benthic primary producers in direct contact with sediments. Based on the available results, the following general recommendations can be formulated to improve the current understanding of pressures and impacts in the management of aquatic ecosystems located in temperate UME.

Although biomagnification was not observed in the present study, further investigations of elemental trophic transfer along benthic food webs appear as a general research priority. This includes accumulation in organisms directly feeding on primary producers, but also transfer from detritivorous invertebrates to predators such as Odonata that could not be sampled in the present study. In the case of primary producers, M. spicatum appears as a valuable tool to better understand the potential adverse effects of $\mathrm{Ni}$ and $\mathrm{Cr}$ because it offers the possibility of combining sediment contact tests in the laboratory with analysis of specimens collected in situ for a single biological model. Overall, the present study shows that proper management of (anthropogenically impacted) aquatic UME requires not only the integration of data from different lines of evidence (geochemistry, ecology and ecotoxicology), but also laboratory vs. field approaches to understand the subtler, long-term effects of increased elemental body burdens in indigenous organisms. 


\section{$\underline{\text { Data availability }}$}

The data about physicochemical parameters in waters and sediments discussed in this study are available through the online database ORDaR (OTELo Research Data Repository) at https://doi.org/10.24396/ORDAR-67 (Minguez et al, 2021).

\section{Credit author statement}

L. Minguez: Conceptualization, Methodology, Resources, Investigation, Validation, Formal analysis, Writing original draft, Visualization, Supervision. E.M. Gross and D.A.L. Vignati: Conceptualization, Methodology, Resources, Investigation, Validation, Writing original draft. A. Romero Freire: Investigation, Writing original draft. E. Camizuli: Formal analysis, Writing original draft. F. Gimbert: Resources, Investigation, Validation, Formal analysis, Writing original draft. C. Caillet: Investigation, Writing original draft. S. Pain-Devin: Writing original draft. S. Devin and F. Guérold: Conceptualization, Writing original draft. L. Giambérini: Conceptualization, Methodology, Resources, Investigation, Validation, Writing original draft, Project administration, Supervision, Funding acquisition.

\section{Declaration of competing interest}

The authors declare that they have no known competing financial interests or personal relationships that could have appeared to influence the work reported in this paper.

\section{Acknowledgements}

The authors would like to thank Aida Bani and Alma Imeri from the Agricultural University of Tirana (Albania) for their help in characterizing study sites, Philippe Wagner for his technical assistance in the field, Philippe Rousselle who carried out chemical analyses, and Sharon Kruger for English corrections. This work has been supported by the French National Research 
Agency through the national program "Investissements d'avenir" with the reference "ANR-10LABX-21-01/LABEX RESSOURCES21”.

\section{References}

APHA, 2005. Standard methods for the examination of water and wastewater, 21st edn. American Public Health Association, Washington, DC.

Bani A., Imeri A., Echevarria G., Pavlova D., Reeves R.D., Morel J.L., Sulçe S., 2013. Nickel hyperaccumulation in the serpentine flora of Albania. Fresen. Environ. Bull. 22(6), 1792-1801. Bani A., Echevarria G., Montargès-Pelletier E., Gjoka F., Sulçe S., Morel J.L., 2014. Pedogenesis and nickel biogeochemistry in a typical Albanian ultramafic toposequence. Environ. Monit. Assess. 186, 4431-4442.

Barko J.W., Smart R.M., 1986. Sediment-related mechanisms of growth limitation in submersed macrophytes. Ecology 67(5), 1328-1340.

Barwick M., Maher W., 2003. Biotransference and biomagnification of selenium copper, cadmium, zinc, arsenic and lead in a temperate seagrass ecosystem from Lake Macquarie Estuary, NSW, Australia. Mar. Environ. Res. 56, 471-502.

Baustian M.M., Hansen G.J.A., de Kluijver A., Robinson K., Henry E.N., Knoll L.B., Rose K.C., Carey C.C., 2014. Linking the bottom to the top in aquatic ecosystems: mechanisms and stressors of benthic-pelagic coupling. Eco-DAS X Chapter 4, 38-60. Doi: 10.4319/ecodas.2014.978-0-9845591-4-5.38.

Bervoets L., De Jonge M., Blust R., 2016. Identification of threshold body burdens of metals for the protection of the aquatic ecological status using two benthic invertebrates. Environ. Pollut. 210, 76-84.

Boening D.W., 1999. An evaluation of bivalves as biomonitors of heavy metals pollution in marine waters. Environ. Monit. Assess. 55, 459-470. 
Burton G., 2018. Breaking from tradition: establishing more realistic sediment quality guidelines. Environ. Sci. Pollut. Res. 25, 3047-3052.

Camizuli E., Scheifler R., Garnier S., Monna F., Losno R., Gourault C., Hamm G., Lachiche C., Delivet G., Chateau C., Alibert P., 2018. Trace metals from historical mining sites and past metallurgical activity remain bioavailable to wildlife today. Sci. Rep. 8, 3436.

Cardwell A.J., Hawker D.W., Greenway M., 2002. Metal accumulation in aquatic macrophytes from southeast Queensland, Australia. Chemosphere 48, 653-663.

Cardwell R.D., DeForest D.K., Brix K.V., Adams W.J., 2013. Do Cd, Cu, Ni, Pb, and Zn biomagnify in aquatic ecosystems? In: Whitacre D.M. (ed.), Reviews of Environmental Contamination and Toxicology Volume 226, Reviews of Environmental Contamination and Toxicology, Springer Science+Business Media New York.

CCME. Canadian environmental quality guidelines - Summary Table. Technical report, Canadian Council of Ministers of the Environment, 2002.

Chen Y., Wang L., Liang T., Xiao J., Li J., Wei H., Dong L., 2018. Major ion and dissolved heavy metal geochemistry, distribution, and relationship in the overlying water of Dongting Lake, China. Environ. Geochem. Health. doi: 10.1007/s10653-018-0204-y

Cui B.S., Zhang Q.J., Zhang K.J., Liu X.H., Zhang H.G., 2011. Analyzing trophic transfer of heavy metals for food webs in the newly-formed wetlands of the Yellow River Delta, China. Environ. Pollut. 159(5), 1297-1306.

de Deckere E., De Cooman W., Leloup V., Meire P., Schmitt C., von der Ohe P.C., 2011. Development of sediment quality guidelines for freshwater ecosystems. J. Soils Sediments 11, 504-517.

Depledge M.H., 1989. Re-evaluation of metabolic requirements for copper and zinc in decapod crustaceans. Mar. Environ. Res. 27(2), 115-126. 
Factoextra, 2018. Extract and Visualize the Results of PCA, CA and MCA. Available online: https://github.com/kassambara/factoextra (accessed on 27 March 2018).

FAO, 2015. Food and Agriculture Organization of the United Nations - Fishery and aquaculture country profile of the Republic of Albania. http://www.fao.org/fishery/facp/ALB/en (accessed 10 July 2018).

Ferrari B.J.D., Vignati D.A.L., Roulier J.L., Coquery M., Szalinska E., Bobrowski A., Czaplicka A., Dominik J., 2019. Chromium bioavailability in aquatic systems impacted by tannery wastewaters. Part 2: New insights from laboratory and in situ testing with Chironomus riparius Meigen (Diptera, Chironomidae). Sci. Total Environ. 653, 1-9.

Gari S.R., Newton A., Icely J.D., 2015. A review of the application and evolution of the DPSIR framework with an emphasis on coastal social-ecological systems. Ocean \& Coastal Management 103, 63-77.

Geng N., Wu Y., Zhang M., Tsang D.C.W., Rinklebe J., Xia Y., Lu D., Zhu L., Niroshika Palansooriya K., Kim K.-H., Ok Y.S., 2019. Bioaccumulation of potentially toxic elements by submerged plants and biofilms: A critical review. Environ. Int. 131, 105015.

Gimbert F., Geffard A., Guedron S., Dominik J., Ferrari B.J.D., 2016. Mercury tissue residue approach in Chironomus riparius: involvement of toxicokinetics and comparison of subcellular fractionation methods. Aquatic Toxicol. 171, 1-8.

Gunnison D., Barko J.W., 1988. The rhizosphere microbiology of rooted aquatic plants. Miscellaneous Paper A-88-4, USAEWES Environmental Laboratory, Washington DC, 41p. Gwenzi W., 2020. Occurrence, behaviour, and human exposure pathways and health risks of toxic geogenic contaminants in serpentinitic ultramafic geological environments (SUGEs): A medical geology perspective. Sci.Total Environ. 700, 134622. 
Harguinteguy C., Pignata M.L., Cirelli, A., 2015. Nickel, lead and zinc accumulation and performance in relation to their use in phytoremediation of macrophytes Myriophyllum aquaticum and Egeria densa. Ecol. Eng. 82, 512-516.

Houba V.J.G., Novozamsky I., Lexmond T.M., Van der Lee J.J., 1990. Applicability of 0.01 M $\mathrm{CaCl} 2$ as a single extraction solution for the assessment of the nutrient status of soils and other diagnostic purposes. Commun. Soil Sci. Plant Anal. 21 (19-20), 2281-2290.

Hseu Z.-Y., Zehetner F., Fujii K., Watanabe T., Nakao A., 2018. Geochemical fractionation of chromium and nickel in serpentine soil profiles along a temperate to tropical climate gradient. Geoderma 327, 97-106.

Jackson L.J., Rowan D.J., Cornett R.J., Kalff J., 1994. Myriophyllum spicatum pumps essential and nonessential trace elements from sediments to epiphytes. Can. J. Fish. Aquat. Sci. 51, 17691773.

Jara-Marini M.E., Soto-Jiménez M.F., Páez-Osuna F., 2009. Trophic relationships and transference of cadmium, copper, lead and zinc in a subtropical coastal lagoon food web from SE Gulf of California. Chemosphere 77, 1366-1373.

Lê S., Josse J., Husson F., 2008. FactoMineR: An R package for multivariate analysis. J. Stat. Softw. 25, 1-18.

Lekaj E., Teqja Z., Bani A., 2019. The dynamics of land covers categories and the impact of climate change on ultramafic areas of Albania. Periodico di Mineralogia, 88(2), 223-234.

Lorenschat, J., Zhang, X., Anselmetti, F., Reed, J., Wessels, M., Schwalb, A., 2014. Recent anthropogenic impact in ancient Lake Ohrid (Macedonia/Albania): a palaeolimnological approach. J. Paleolimnol. 52, 139-154.

MacDonald D.D., Ingersoll C.G., Berger T.A., 2000. Development and Evaluation of Consensus-Based Sediment Quality Guidelines for Freshwater Ecosystems. Arch. Environ. Contam. Toxicol. 39(1), 20-31. 
Malaj E., Rousseau D.P.L., Du Laing G., Lens P.N.L., 2012. Near-shore distribution of heavy metals in the Albanian part of Lake Ohrid. Environ. Monit. Assess. 184, 1823-1839.

Marescotti P., Comodi P., Crispini L., Gigli L., Zucchini A., Fornasaro S., 2019. Potentially toxic elements in ultramafic soils: A study from metamorphic ophiolites of the Voltri Massif (Western Alps, Italy). Minerals 9, 502.

Marvin C., Grapentine L., Painter S., 2004. Application of a Sediment Quality Index to the Lower Laurentian Great Lakes. Environ. Monit. Assess. 91(1-3), 1-16.

Mazej Z., Al Sayegh-Petkovšek S., Pokirny B., 2010. Heavy metal concentrations in food chain of Lake Velenjsko jezero, Slovenia: An artificial lake from mining. Arch. Environ. Contam. Toxicol. 58, 998-1007.

[dataset] Minguez L., Gross E.M., Vignati D.A.L., Romero Freire A., Camizuli E., Gimbert F., Caillet C., Pain-Devin S., Devin S., Guérold F., Giambérini L., 2021. Data for: Profiling metal contamination from ultramafic sediments to biota along the Albanian shoreline of Lake Ohrid (Albania/Macedonia); ORDaR, OTELo Research Data Repository; doi: 10.24396/ORDAR-67. MicroBioTest, 2001. OstracodToxKit FTM "Direct Contact" Toxicity Test for Freshwater Sediments. Standard Operational Procedure, Deinze, Belgium, p. 34.

Nicolas A., Boudier F., Meshi A., 1999. Slow spreading accretion and mantle denudation in the Mirdita ophiolite (Albania). J. Geophys. Res. Solid Earth, 104(B7), 15155-15167.

Nordberg M., Templeton D.M., Andersen O., Duffus J.H., 2009. Glossary of terms used in ecotoxicology (IUPAC Recommendations 2009). Pure Appl. Chem. 81(5), 829-970.

OECD Guideline 218, 2004. Sediment-water chironomid toxicity using spiked sediment, pp 121. doi:10.1787/9789264070264-en.

Quevauviller, Ph., Rauret, G., López-Sanchez, J.L., Rubio, R., Ure, A., Muntau, H., 1997. Certification of trace metal extractable contents in a sediment reference material (CRM601) following a three-step sequential extraction procedure. Sci. Total Environ. 205, 223-234. 
Papagiannis I., Kagalou I., Leonardos J., Petridis D., Kalfakakou V., 2004. Copper and zinc in four freshwater fish species from Lake Pamvotis (Greece). Environ. Int. 30, 357-362.

Post D.M., 2002. Using stable isotopes to estimate trophic position: models, methods, and assumptions. Ecology 83(3), 703-718.

Post D.M., Layman C.A., Arrington D.A., Takimoto G., Quattrochi J., Montaña C.G., 2007. Getting the fat of the matter: models, methods and assumptions for dealing with lipids in stable isotope analyses. Oecologia 152, 179-189.

R Core Team, 2019. R: A language and environment for statistical computing. R Foundation for statistical computing, Vienna. https://www.R-project.org

Ravera O., Cenci R., Beone G.M., Dantas M., Lodigiano P., 2003. Trace element concentrations in freshwater mussels and macrophytes as related to those in their environment. J. Limnol. 62(1), 61-70.

Reeves R.D., Baker A.J.M., 2000. Metal-accumulating plants. In: Raskin I., Ensley B.D. (Eds.) Phytoremediation of toxic metals: using plants to clean up the environment. New York, USA: John Wiley, 193-229.

Rosabal M., Hare L., Campbell P.G.C., 2014. Assessment of a subcellular metal partitioning protocol for aquatic invertebrates: preservation, homogenization and subcellular fractionation. Limnol. Oceanogr.: Methods, 12, 507-518.

Rzymski P., Niedzielski P., Klimaszyk P., Poniedzialek B., 2014. Bioaccumulation of selected metals in bivalves (Unionidae) and Phragmites australis inhabiting a municipal water reservoir. Environ. Monit. Assess. 186, 3199-3212.

Schwertmann, U., 1964. Differenzierung der Eisenoxide des Bodens durch Extraktion mit Ammonium-Lösung. Z. Pflanzenernähr. Düng. Bodenk. 105(3), 194-202.

Sibal L.N., Espino M.P.B., 2018. Heavy metals in lake water: a review on occurrence and analytical determination. Inter. J. Environ. Anal. Chem. 98:6, 536-554, 
Sinopoli G., Peyron O., Masi A., Holtvoeth J., Francke A., Wagner B., Sadori L., 2019. Pollenbased temperature and precipitation changes in the Ohrid Basin (western Balkans) between 160 and 70 ka. Clim. Past, 15, 53-71.

Ure AM, Quevauviller Ph., Muntau H Griepink B., 1993. Speciation of heavy metals in soils and sediments. An account of the improvement and harmonization of extraction techniques undertaken under the auspices of the BCR of the Commission of European Communities. Intern J Environ Anal Chem 51: 135-151.

Vadeboncoeur Y., Vander Zanden M.J., Lodge D.M., 2002. Putting the lake back together: Reintegrating benthic pathways into lake food web models. BioScience 52(1), 44-54.

Vangheluwe M.L.U., Verdonck F.A.M., Besser J.M., Brumbaugh W.G., Ingersoll C.G., Schlekat C.E., Rogevich Garman E., 2013. Improving sediment-quality guidelines for nickel: development and application of predictive bioavailability models to assess chronic toxicity of nickel in freshwater sediments. Environ. Toxicol. Chem. 32(11), 2507-2519.

Varol M., 2011. Assessment of heavy metal contamination in sediments of the Tigris River (Turkey) using pollution indices and multivariate statistical techniques. J. Hazard. Mater. 195, 355-364.

Vithanage M., Kumarathilaka P., Oze C., Karunatilake S., Seneviratne M., Hseu Z.-Y., Gunarathne V., Dassanayake M., Ok Y.S., Rinklebe J., 2019. Occurrence and cycling of trace elements in ultramafic soils and their impacts on human health: A critical review. Environ. Int. $131,104974$.

Vogel H., Wessels M., Albrecht C., Stich H.-B., Wagner B., 2010. Spatial variability of recent sedimentation in Lake Ohrid (Albania/Macedonia). Biogeosciences 7, 3333-3342.

Wang W.X., 2002. Interactions of trace metals and different marine food chain. Mar. Ecol. Prog. Ser. 243, 295-309. 
Ward D.M., Mayes B., Sturup S., Folt C.L., Chen C.Y., 2012. Assessing element-specific patterns of bioaccumulation across New England lakes. Sci. Total Environ. 421-422, 230-237. Weis J.S., Weis P., 2004. Metal uptake, transport and release by wetland plants: implications for phytoremediation and restoration. Environ. Inter. 30, 685-700.

White S.L., Rainbow P.S., 1985. On the metabolic requirements for copper and zinc in molluscs and crustaceans. Mar. Environ. Res. 16, 215-229.

Xing X., Ding S., Liu L., Chen M., Yan W., Zhao L., Zhang C., 2018. Direct evidence for the enhanced acquisition of phosphorus in the rhizosphere of aquatic plants: A case study on Vallisneria natans. Sci. Total Environ. 616-617, 386-396.

Xing W., Wu H., Hao B., Huang W., Liu G., 2013. Bioaccumulation of heavy metals by submerged macrophytes: Looking for hyperaccumulators in eutrophic lakes. Environ. Sci. Technol. 47, 4695-4703.

Xu Y., Wu Y., Han J., Li P., 2017. The current status of heavy metal in lake sediments from China: Pollution and ecological risk assessment. Ecology and Evolution 7, 5454-5466. 


\section{Table and Figures}

Table 1. Trace element concentrations measured in sediments from sites Pog, Mem, Poj and Pis using pseudo-total and partial extraction procedures (see text for details). All values are in $\mathrm{mg} \mathrm{kg}^{-1}$ dry weight.

\begin{tabular}{lccccccc}
\hline & $\mathrm{Cu}$ & $\mathrm{Co}$ & $\mathrm{Cr}$ & $\mathrm{Fe}$ & $\mathrm{Mn}$ & $\mathrm{Ni}$ & $\mathrm{Zn}$ \\
\hline PEC $^{\mathrm{a}}$ & 149 & NA & 111 & NA & NA & 48.6 & 459
\end{tabular}

Pog:

$\begin{array}{llllllll}\text { Pseudo-total } & 5 & 4.2 & 17.6 & 7067 & 241 & 23.2 & 18.7\end{array}$

$\begin{array}{llllllll}\mathrm{CaCl}_{2} & 0.04 & 0 & 0 & 0 & 0.127 & 0.009 & 1.46\end{array}$

$\begin{array}{llllllll}\text { EDTA } & 0.93 & 0.166 & 0.176 & 74.6 & 81.7 & 0.491 & 1.28\end{array}$

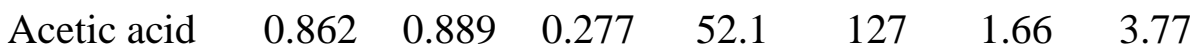

$\begin{array}{lllllllll}\text { Oxalic acid } & - & - & - & 1943 & 81.1 & - & -\end{array}$

\section{Mem:}

\begin{tabular}{lccccccc}
\hline Pseudo-total & 6.2 & 24.3 & 137 & 18282 & 283 & $\mathbf{5 5 4}$ & 21.5 \\
$\mathrm{CaCl}_{2}$ & 0.022 & 0.001 & 0 & 0.019 & 0.189 & 0.153 & 1.84 \\
EDTA & 0.953 & 1.21 & 0.384 & 112 & 40.1 & 4.95 & 0.728 \\
Acetic acid & 0.348 & 4.76 & 0.994 & 112 & 103 & 17.3 & 1.42 \\
Oxalic acid & - & - & - & 5256 & 117 & - & -
\end{tabular}

\section{Poj:}

$\begin{array}{llllllll}\text { Pseudo-total } & 16.4 & 93.8 & \mathbf{2 4 5} & 45955 & 873 & \mathbf{1 0 0} & 64.2\end{array}$

$\begin{array}{llllllll}\mathrm{CaCl}_{2} & 0.004 & 0 & 0.05 & 0 & 0.12 & 0.062 & 0.054\end{array}$

$\begin{array}{llllllll}\text { EDTA } & 2.82 & 2.72 & 0.949 & 125 & 87.2 & 16.2 & 2.2\end{array}$

$\begin{array}{llllllll}\text { Acetic acid } & 0 & 1.41 & 0.206 & 0 & 129 & 25.2 & 0.516\end{array}$

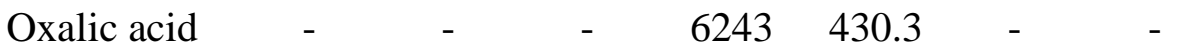

Pis:

$\begin{array}{llllllll}\text { Pseudo-total } & 11.5 & 92.2 & \mathbf{3 4 5} & 49915 & 742 & \mathbf{1 1 2} & 35.5\end{array}$

$\begin{array}{llllllll}\mathrm{CaCl}_{2} & 0.017 & 0 & 0.032 & 0 & 0.261 & 0.137 & 0.034\end{array}$

$\begin{array}{llllllll}\text { EDTA } & 1.12 & 1.42 & 0.54 & 73 & 49.7 & 4.67 & 1.03\end{array}$

$\begin{array}{llllllll}\text { Acetic acid } & 0 & 0.91 & 0.112 & 0 & 70.4 & 14 & 1.78\end{array}$

$\begin{array}{llllllll}\text { Oxalic acid } & - & - & - & 7226 & 199 & - & -\end{array}$

a PEC: levels above which harmful effects on sediment-dwelling organisms are expected to occur, concentrations above guidelines are in bold. NA: Non-available 


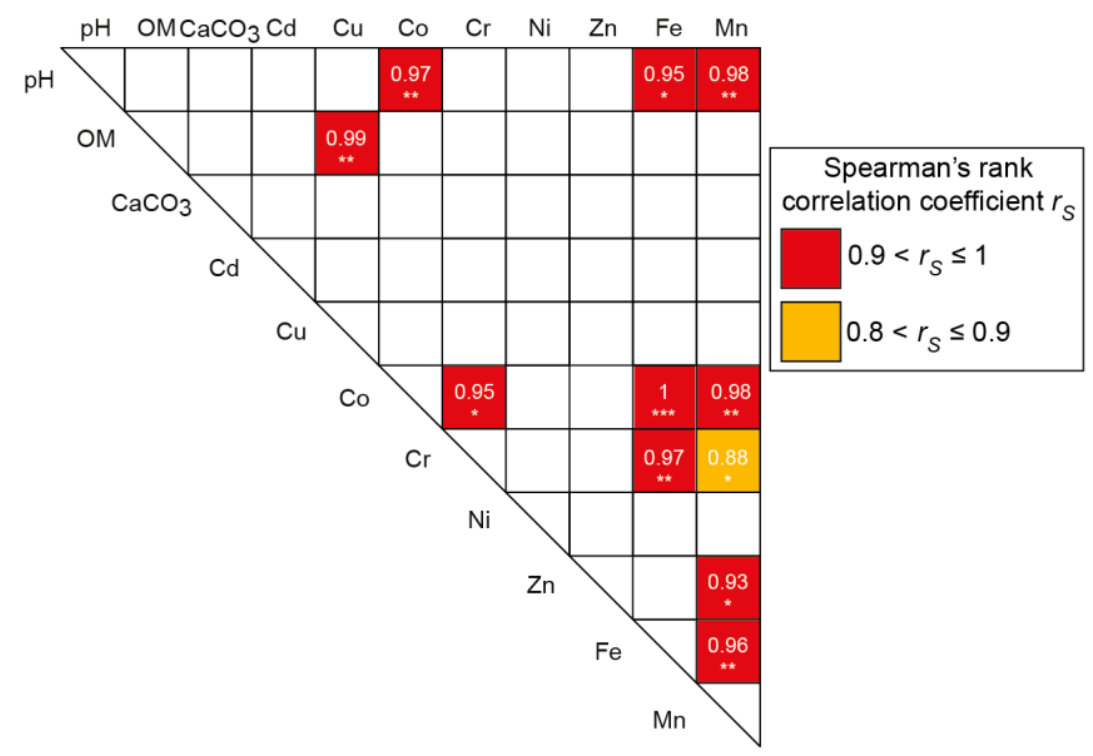

Figure 1. Matrix of spearman correlations between pseudo-total metal concentrations in sediments and properties of sediments. $* * *$ for $\mathrm{p}<0.001$, ** for $\mathrm{p}<0.01$, * for $\mathrm{p}<0.05$. Empty boxes indicate the absence of significant correlations. 

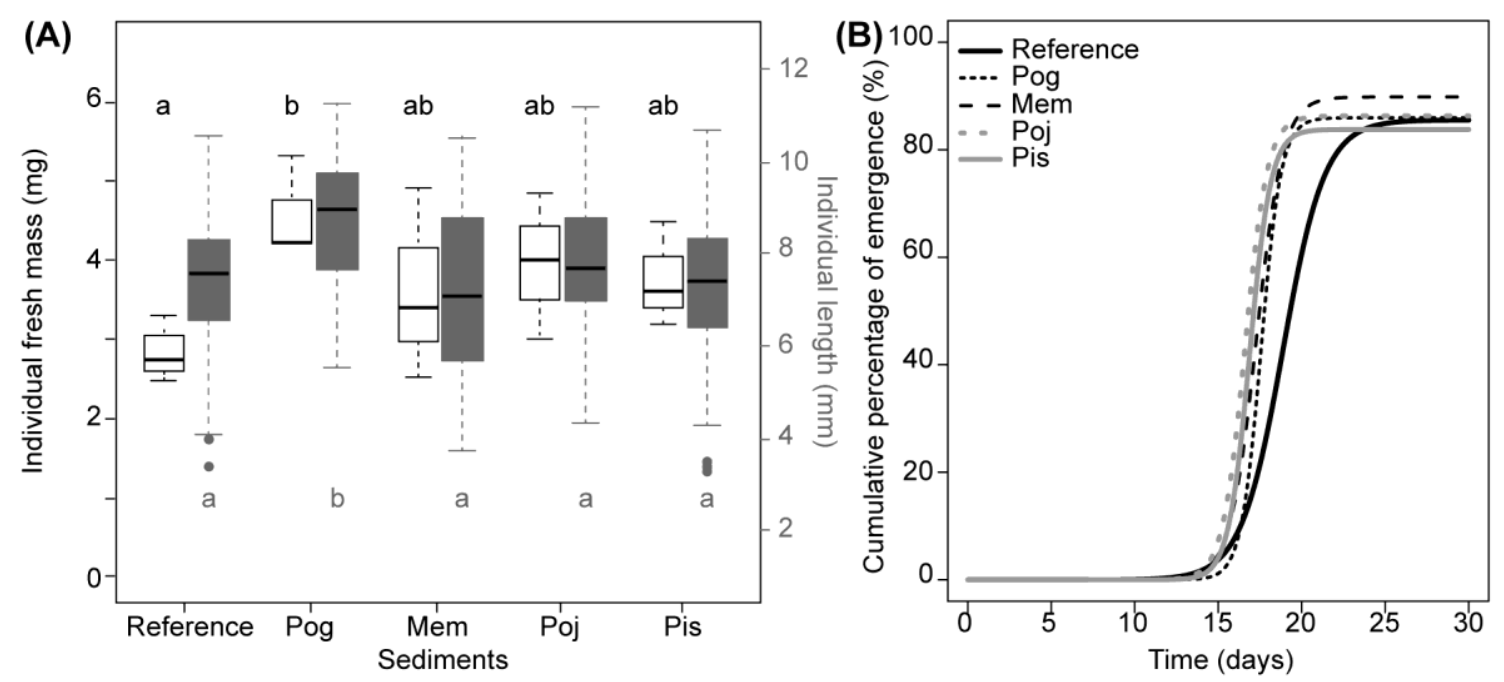

Figure 2. Ecotoxicity assessment of lake sediments on chironomids. A reference non-toxic sediment (sand) was also tested. (A) Individual fresh mass ( $\mathrm{n}=3$, white boxes) and length ( $\mathrm{n}=60$, grey boxes) of $C$. riparius. Box plots show the median values, quartiles ("hinges"), extremes (“whiskers") and outliers (dots). Different letters indicate significant differences. (B) Logistic modelling of the time course of the cumulative percentage of $C$. riparius emergence for the different treatments.

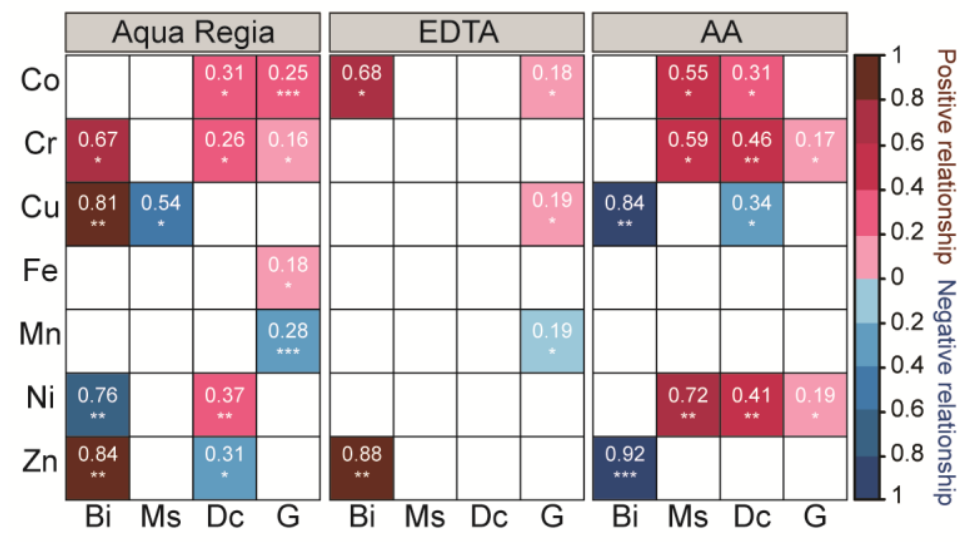

Figure 3. Linear correlation coefficients $\left(r_{S}\right)$ between pseudo-total metal concentrations in sediments (aqua regia extraction), concentrations after EDTA or acetic acid (AA) extractions and concentrations in organisms. *** for $\mathrm{p}<0.001$, ** for $\mathrm{p}<0.01$, * for $\mathrm{p}<0.05$. Different colors are used according to the direction of the relationship (right scale). Legend: periphytic biofilm (Bi), M. spicatum (Ms), D. carinata (Dc), Gammarus sp. (G). 


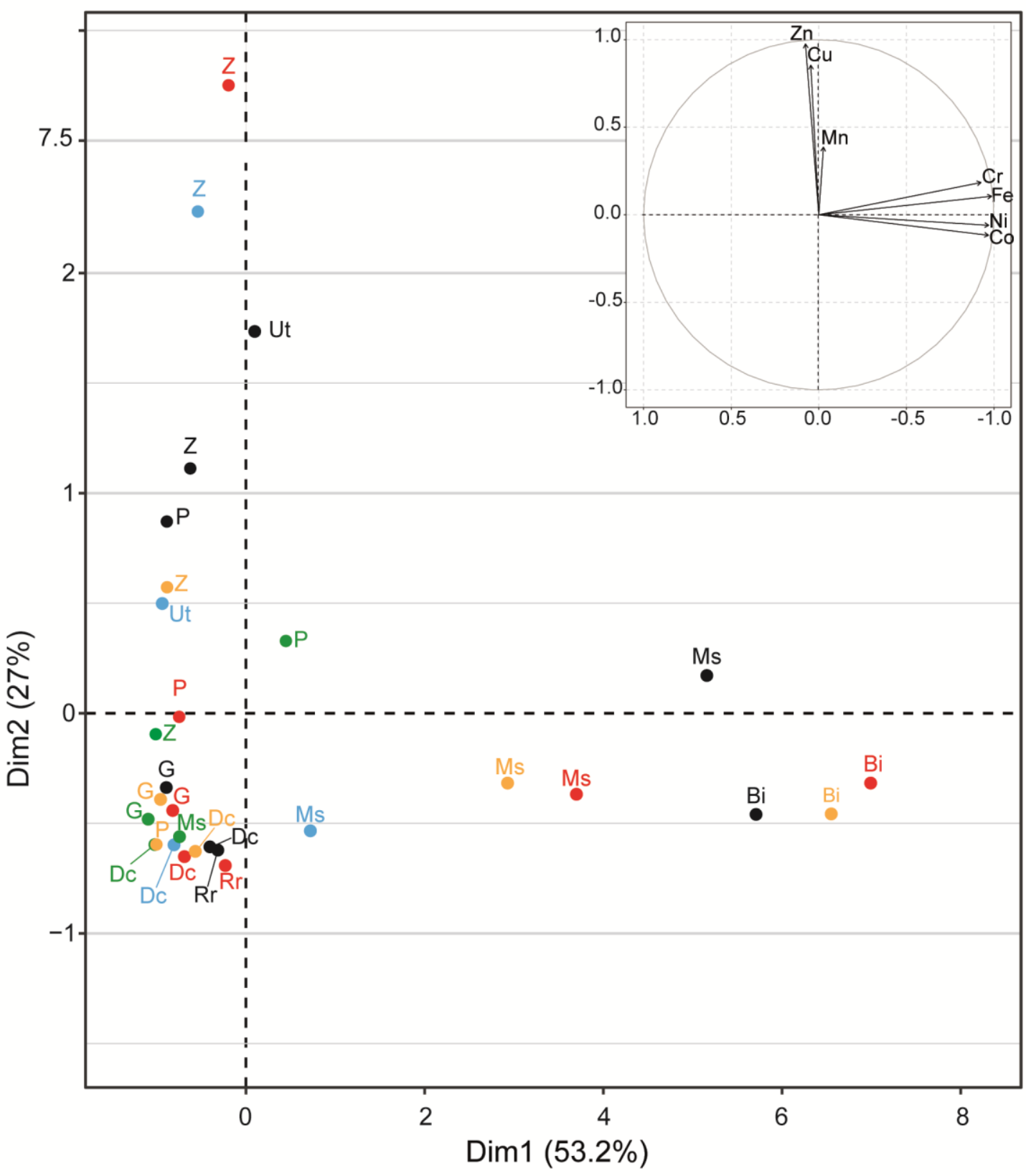

Figure 4. Principal component analysis based on metal contents in primary producers and depurated invertebrates at the five study sites (Pog in blue, Mem in black, Poj in red, Pis in orange and Lin in green). Legend: Phytoplankton (P), periphytic biofilm (Bi), M. spicatum (Ms), zooplankton (Z), D. carinata (Dc), U. tumidus (Ut), R. relicta (Rr) and Gammarus sp. (G). 


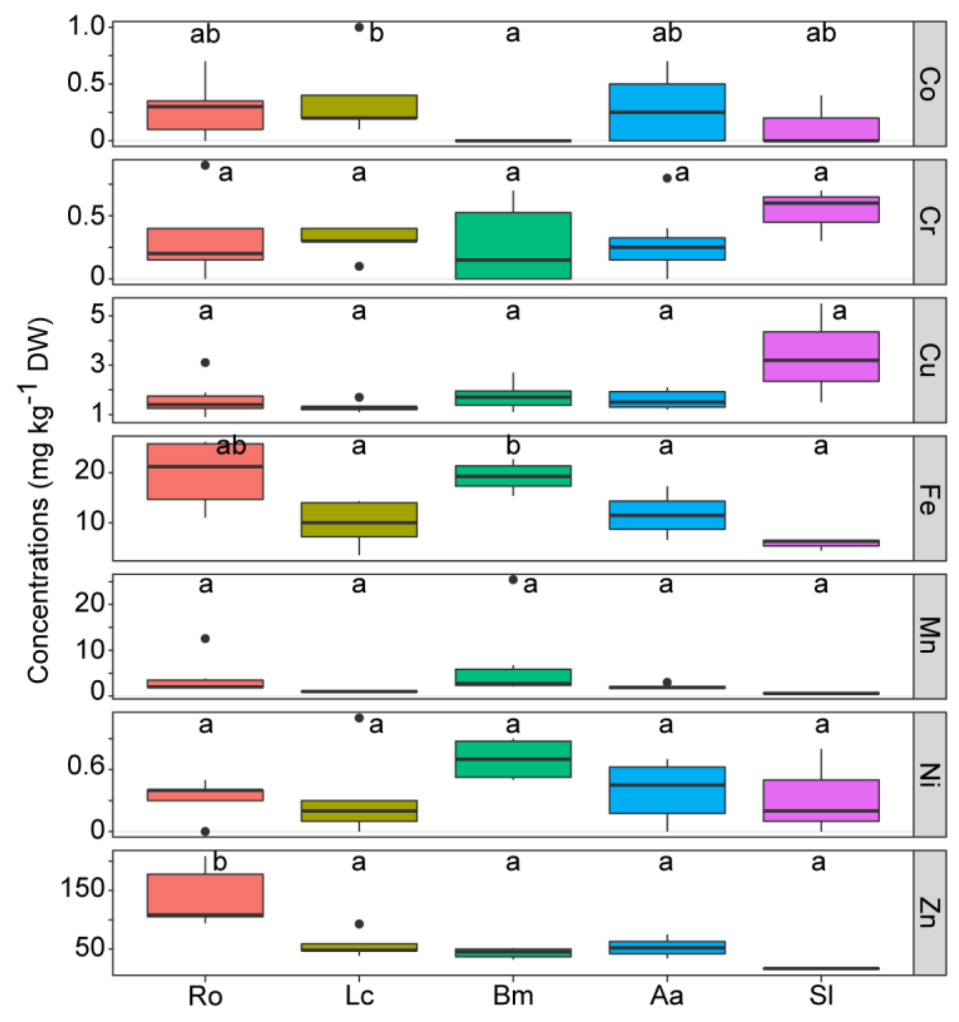

Figure 5. Boxplot of metal concentrations ( $\mathrm{mg} \mathrm{kg}^{-1}$ dry weight) bioaccumulated in fish muscles. Fish species are R. ohridanus (Ro), L. cephalus albus (Lc), B. meridionalis petenyi (Bm), A. albidus (Aa) and S. letnica (Sl). Box plots show the median values, quartiles ("hinges"), extremes ("whiskers") and outliers (dots). Different lowercase letters indicate significant differences in metal concentrations in a given organ between fish species. 


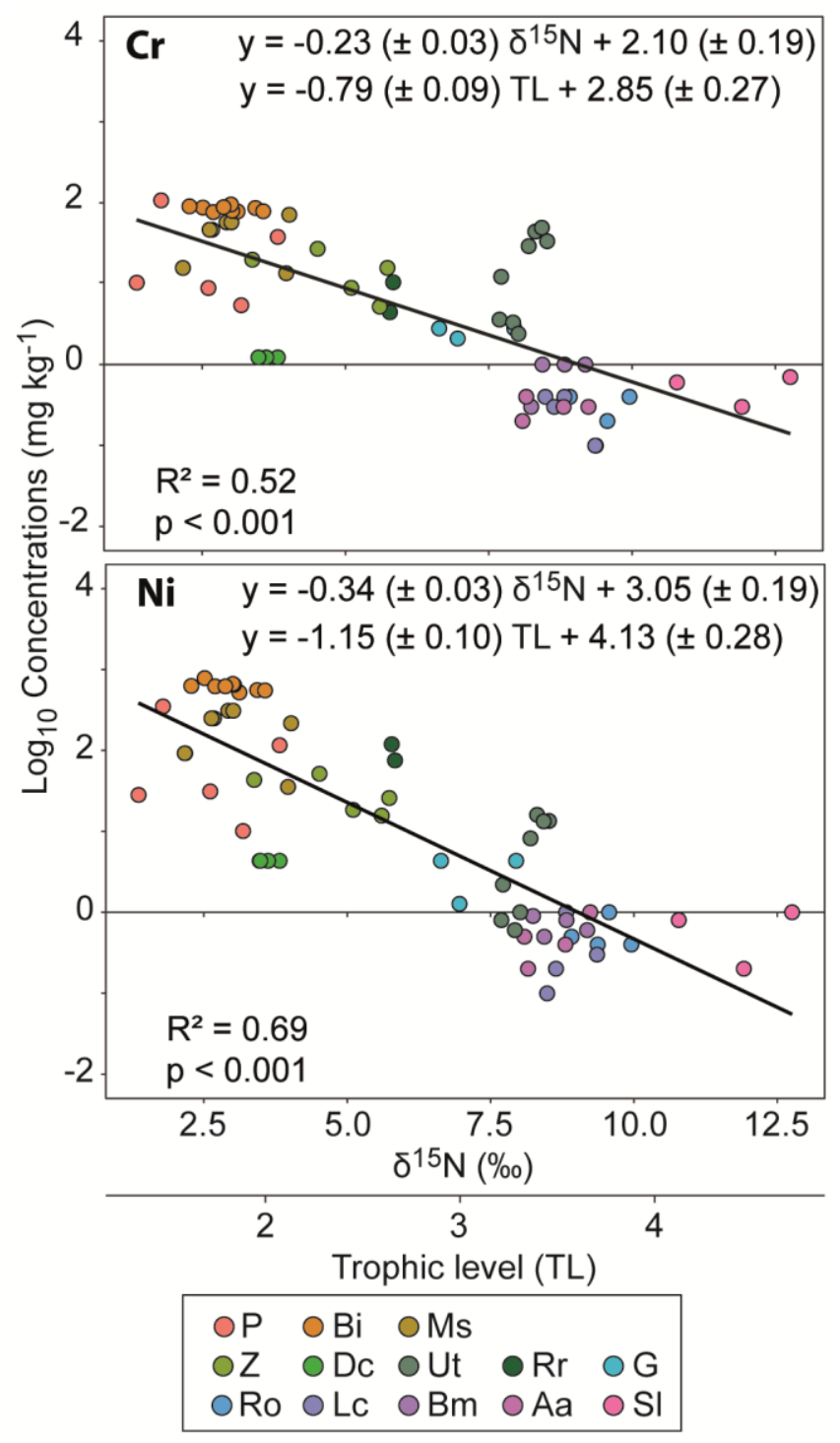

Figure 6. Logarithm of $\mathrm{Cr}$ and $\mathrm{Ni}$ concentrations ( $\mathrm{mg} \mathrm{kg}^{-1}$ dry weight) as a function of $\delta^{15} \mathrm{~N}$ values and trophic level (TL). See legends of Fig. 4 and 5 for species codes. 